\title{
COPPER AND CERULOPLASMIN CONTENTS IN THE BLOOD SERUM OF PERIPHERAL AND PRE-HEPATIC VEINS
}

\author{
H. M. Canelas \\ I. ROITMAN \\ M. SCAFF \\ S. RAIA \\ F. B. DE JORGE
}

Several questions about the pathogenesis of hepatolenticular degeneration (HLD) remain unsolved, despite the extraordinary results achieved by the numerous researches carried out, mainly with radioactive copper $9,11,12$. For instance, the low copper content of the stools, formerly ascribed to an increased intestinal absorption ${ }^{16}$, is now regarded as a consequence of a defective biliary excretion 5,10 .

However, although some facts ${ }^{5,6,8}$ seem to question the significance of the impaired synthesis of ceruloplasmin, the investigations with radiocopper ${ }^{12}$ and other arguments $12,13,15$ apparently support it.

In an attempt to contribute for the unraveling of the problem, the concentrations both of copper and ceruloplasmin have been determined in samples of peripheral and pre-hepatic venous blood from 11 patients submitted to portal decompression.

\section{MATERIAL AND METHODS}

During the performance of either porto-caval or spleno-renal shunt in 11 patients with Manson's hepato-splenic schistosomiasis, blood samples from the superior mesenteric and basilic veins were collected.

Ceruloplasmin and copper contents were determined according to Houchin ${ }^{\tau}$ and a modified Gubler method ${ }^{3}$, respectively. Due care was taken in order to prevent copper contamination of the materials.

The results obtained in the samples of peripheral blood, compared to normal values ", ", showed increased copper contents in 6 cases, while all ceruloplasmin levels fitted in the normal range. In these cases, the increase of the direct reacting copper may be due to the liver damage caused by schistosomiasis.

For comparative purposes, the same study was done in a patient with HLD submitted to porto-caval shunt owing to a severe bleeding of esophageal varices.

The results were submitted to statistical treatment, by means of the analysis of the individual differences in the copper and ceruloplasmin contents of both blood samples ${ }^{1}$.

From the Departments of Neuropsychiatry (Division of Neurology) and Surgery (3 ${ }^{\text {rd }}$ Division) of the University of São Paulo Medical School. 


\section{RESULTS}

The results obtained in the 11 schistosomic patients are assembled in table 1 . In the patient with Wilson's disease no ceruloplasmin could be demonstrated in any of the samples, by the method employed. On the other hand, determination of the total copper content showed $30 \mu \mathrm{g} / 100$ in the basilic vein blood, 30 in vena cava, 22 in the hepatic vein and 10 in the portal vein.

\begin{tabular}{|c|c|c|c|c|c|c|}
\hline \multirow[t]{2}{*}{ Case } & \multirow[t]{2}{*}{ Name } & \multirow[t]{2}{*}{ File n.o } & \multicolumn{2}{|c|}{ Basilic } & \multicolumn{2}{|c|}{ Superior mesenteric } \\
\hline & & & $\begin{array}{c}\text { Copper } \\
(\mu \mathrm{g} / 100 \mathrm{ml})\end{array}$ & $\begin{array}{c}\text { Cerulo- } \\
\text { plasmin } \\
(\mathrm{mg} / 100 \mathrm{ml})\end{array}$ & $\begin{array}{c}\text { Copper } \\
(\mu \mathrm{g} / 100 \mathrm{ml})\end{array}$ & $\begin{array}{c}\text { Cerulo- } \\
\text { plasmin } \\
(\mathrm{mg} / 100 \mathrm{ml})\end{array}$ \\
\hline 1 & M.N.A. & 1088092 & $275^{*}$ & 25.5 & $315^{*}$ & 34.3 \\
\hline 2 & L.R.S. & 1087770 & 80 & 21.5 & 75 & 19.7 \\
\hline 3 & C.A.C. & 1087499 & 95 & 28.0 & 107 & 27.8 \\
\hline 4 & C.A.A. & 1059286 & 123 & 29.4 & 109 & 25.0 \\
\hline 5 & J.L.P. & 1089501 & $130^{*}$ & 28.0 & 115 & 25.0 \\
\hline 6 & O.F.S. & 1091351 & 115 & 31.6 & 70 & 13.6 \\
\hline 7 & D.P.P. & $1 \mathrm{C} 87803$ & 一 & 28.0 & $一$ & 32.0 \\
\hline 8 & B.F.S. & 1046037 & $190^{*}$ & 39.0 & $180 *$ & 38.0 \\
\hline 9 & M.G.S.M. & 1046772 & $130^{*}$ & 29.0 & $130^{*}$ & 32.0 \\
\hline 10 & B.S.A. & 1103385 & $160^{*}$ & 26.0 & $150^{*}$ & 27.0 \\
\hline 11 & V.A.S. & 1047166 & $150^{*}$ & 33.0 & $160^{*}$ & 27.0 \\
\hline \multicolumn{3}{|c|}{ Statistical analysis } & d & $\mathrm{t}$ & $\mathrm{P}$ & \\
\hline \multicolumn{3}{|c|}{ Copper } & 3.6 & 0.536 & $\simeq 0.60$ & \\
\hline \multicolumn{3}{|c|}{ Ceruloplasmin } & 17.6 & 0.777 & $\simeq 0.45$ & \\
\hline
\end{tabular}

Table 1 - Results: * high blood copper contents.

\section{DISCUSSION}

Trip ${ }^{14}$, using vascular catheterization, has determined the blood copper and ceruloplasmin contents in the brachial artery and in the hepatic and subclavian veins of 37 patients. Of the 37 patients, 25 had liver cirrhosis or other hepatic pathology, and 12 had heart diseases. Total blood copper and ceruloplasmin contents in the brachial artery were lower than in the hepatic vein. From his investigations, the author drew the conclusion that the ceruloplasmin in synthesized in the liver as fraction I (C-C), which is carried to the tissues by the blood stream, part of it being inactivated or destroyed, part transformed in fraction II (C-D), and part staying in the blood as fraction $I$.

In our material, the differences between the copper and ceruloplasmin contents in the samples of peripheral and pre-hepatic blood were not significant, a fact which could be anticipated due to the wide disfersion of the results (Table I). 
Our results, arising from an essentially different approach than Trip's, suggest that the copper content in the blood from the small bowel is not higher than that of the periperal blood. The same result was obtained regarding ceruloplasmin*, probably because the mesenteric blood contains an appreciable amount of elements coming from the general circulation. Therefore, the mesenteric blood differs in this regard from lymph, which contains no ceruloplasmin ${ }^{14}$.

In the patient with HLD the copper content in the portal vein was markedly lower than in vena cava and the basilic vein $(10 \mu \mathrm{g} / 100 \mathrm{ml}$ instead of 30 ). This seems to indicate that, in Wilson's disease, even a decrease in the intestinal absorption of copper can be observed.

\section{SUMMARY}

Copper and ceruloplasmin contents were determined in samples of peripheral and pre-hepatic venous blood of 11 patients with Manson's schistosomiasis and one patient with hepatolenticular degeneration, all of çhich submitted either to porto-caval or spleno-renal shunt. Individual difference were not significant in any of the non-Wilsonian patients. The results are discussed in regard to the current knowledge on the pathogenesis of Wilson's disease.

\section{RESUMO \\ Concentrações de cobre e ceruloplasmina no soro sanguineo de veias periférica e pré-hepática}

Foram determinadas as concentrações de cobre e ceruloplasmina em amostras de sangue venoso periférico e pré-hepático de 11 pacientes esquistossomóticos e de 1 paciente com degeneração hepatolenticular, submetidos a anastomose portocava ou esplenorrenal. Nos 11 pacientes não wilsonianos, as diferenças individuais não se revelaram estatisticamente significantes. Os resultados são comentados em relação aos conhecimentos atuais sobre a patogenia da moléstia de Wilson.

\section{REFERENCES}

1. BERNSTEIN, L. \& WEATHERALL, M. - Statistics for Medical and other Biological Students. Livingstone, Edinburgh, 1952, pp. 85-88.

2. DE JORGE, F. B. \& CANELAS, H. M. - Contribuição ao estudo da ceruloplasmina: valores normais no soro sanguineo. Arq. Neuro-Psiquiat (São Paulo) $22: 271,1964$.

3. DE JORGE, F. B.; CANElas, H. M. \& COSTA-SIlva, A. - Contribuição ao estudo do metabolismo do cobre: metodologia da determinação do cobre em materiais biológicos. Rev. paul. Med. 61:350, 1962.

- Although the mean difference of the copper contents is less significant than that of the ceruloplasmin contents (table 1). 
4. DE JORGE, F. B.; CANELAS, H. M. \& SPINA-FRANCA, A. - Contribuição ao estudo do metabolismo do cobre: valores normais no sangue, líquido cefalorraqueano e urina. Rev. paul. Med. 62:125, 1963.

5. FROMMER, D. J. - Defective biliary excretion of copper in Wilson's disease. Gut 15:125, 1974 .

6. GOLDSTEIN, W. P. \& OWEN, C. A. - Introduction. Symposium of copper metabolism and Wilson's disease. Mayo Clin. Proc. 49:363, 1974.

7. HOUCHIN, O. B. - A rapid colorimetric method for the quantitative determination of copper oxidase activity (ceruloplasmin). Clin. Chem. 4:519, 1958.

8. O'REILLY, S. - Problems in Wilson's disease. Neurology (Minneapolis) 17: 137, 1967.

9. O'REILly, S.; POLLYCOVE, M.; TONO, M. \& HERRADORA, L. - Abnormalities of the physiology of copper in Wilson's disease: the internal kinetics of copper. Arch. Neurol. (Chicago) 24:481, 1971.

10. O'REILLY, S.; WEBER, P. M.; OSWALD, M. \& SHIPLEY, L. - Abnormalities of the physiology of copper in Wilson's disease: the excretion of copper. Arch. Neurol. (Chicago) 25:28, 1971.

11. OSBORN, S. \& WALSHE, J. M. - Copper uptake by the liver: study of a Wilson's disease family. In J. M. Walshe \& J. N. Cumings - Wilson's Disease, Some Current Concepts. Blackwell, Oxford, 1961, p. 141.

12. SASS-KORTSAK, A.; CHERNIAK, M.; GEIGER, D. W. \& SLATER, R. J. Observations on ceruloplasmin in Wilson's disease. J. clin. Invest. 38:1672, 1959 .

13. SCHEINBERG, I. H. \& MORELL, A. G. - Ceruloplasmin. In G. Eichhorn Inorganic Biochemistry. Elsevier, Amsterdam, 173, vol. 1, chapter 10, p. 306.

14. TRIP, J. A. J. - Ceruloplasmin: Clinical and Experimental Investigations on Origin, Presence and Behavior of Fractions. Wolters-Noorhoff, Groningen, 1968.

15. WALSHE, J. M. - The physiology of copper in man and its relation to Wilson's disease. Brain 90:149, 1967.

16. ZIMDAHL, 'W. T.; HYMAN, I. \& COOK, E. D. - Metabolism of copper in hepatolenticular degeneration. Neurology (Minneapolis) 3:569, 1953 .

Departamento de Neuropsiquiatria, Divisão de Neurologia - Faculdade de Medicina, Universidade de São Paulo - Caixa Postal 3461 - 01000 São Paulo. $\mathrm{SP}$ - Brasil. 